\title{
Morphologies and Electronic Structures of Calcium-Doped Ceria Model Catalysts and Their Interaction with $\mathrm{CO}_{2}$
}

\author{
WANG Yan, LI Xiong, HU Shanwei ${ }^{*}$, XU Qian, JU Huanxin, ZHU Junfa * \\ National Synchrotron Radiation Laboratory, Department of Chemical Physics, University of Science and Technology of China, \\ Hefei 230029, P. R. China.
}

\begin{abstract}
CeO}_{2}$-based catalysts are promising for use in various important chemical reactions involving $\mathrm{CO}_{2}$, such as the dry reforming of methane to produce synthesis gas and methanol. $\mathrm{CeO}_{2}$ has a superior ability to store and release oxygen, which can improve the catalytic performance by suppressing the formation of coke. Although the adsorption and activation behavior of $\mathrm{CO}_{2}$ on the $\mathrm{CeO}_{2}$ surface has been extensively investigated in recent years, the intermediate species formed from $\mathrm{CO}_{2}$ on ceria has not been clearly identified. The reactivity of the ceria surface to $\mathrm{CO}_{2}$ has been reported to be tuned by introducing
\end{abstract}

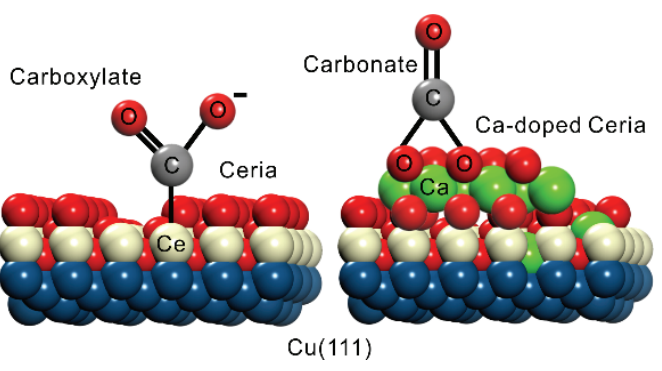
$\mathrm{CaO}$, which increases the number of basic sites for the ceria-based catalysts. However, the mechanism by which $\mathrm{Ca}^{2+}$ ions affect $\mathrm{CO}_{2}$ decomposition is still debated. In this study, the morphologies and electronic properties of stoichiometric $\mathrm{CeO}_{2}$ (111), partially reduced $\mathrm{CeO}_{2-x}(111)(0<x<0.5)$, and calcium-doped ceria model catalysts, as well as their interactions with $\mathrm{CO}_{2}$, were investigated by scanning tunneling microscopy (STM), X-ray photoelectron spectroscopy, and synchrotron radiation photoemission spectroscopy. Stoichiometric $\mathrm{CeO}_{2}(111)$ and partially reduced $\mathrm{CeO}_{2-x}(111)$ films were epitaxially grown on a $\mathrm{Cu}(111)$ surface. STM images show that the stoichiometric $\mathrm{CeO}_{2}$ film exhibits large, flat terraces that completely cover the $\mathrm{Cu}(111)$ surface. The reduced $\mathrm{CeO}_{2-x}$ film also has a flat surface and an ordered structure, but dark spaces are observed on the film. Different Ca-doped ceria films were prepared by physical vapor deposition of metallic $\mathrm{Ca}$ on $\mathrm{CeO}_{2}(111)$ at room temperature and subsequent annealing to 600 or $800 \mathrm{~K}$ in ultrahigh vacuum. The different preparation procedures produce samples with various surface components, oxidation states, and structures. Our results indicate that the deposition of metallic $\mathrm{Ca}$ on $\mathrm{CeO}_{2}$ at room temperature leads to a partial reduction of $\mathrm{Ce}$ from the +4 to the +3 state, accompanied by the oxidation of $\mathrm{Ca}$ to $\mathrm{Ca}^{2+}$. Large $\mathrm{CaO}$ nanofilms are observed on $\mathrm{CeO}_{2}$ upon annealing to $600 \mathrm{~K}$. However, small $\mathrm{CaO}$ nanoislands appear near the step edges and more $\mathrm{Ca}^{2+}$ ions migrate into the subsurface of $\mathrm{CeO}_{2}$ upon annealing to $800 \mathrm{~K}$. In addition, different surface-adsorbed species are identified after $\mathrm{CO}_{2}$ adsorption on ceria $\left(\mathrm{CeO}_{2}\right.$ and reduced $\left.\mathrm{CeO}_{2-x}\right)$ and $\mathrm{Ca}$-doped ceria films. $\mathrm{CO}_{2}$ adsorption on the stoichiometric $\mathrm{CeO}_{2}$ and partially reduced $\mathrm{CeO}_{2-x}$ surfaces leads to the formation of surface carboxylate. Moreover, the surface carboxylate species is more easily formed on reduced $\mathrm{CeO}_{2-x}$ with enhanced thermal stability than on stoichiometric $\mathrm{CeO}_{2}$. On Ca-doped ceria films, the presence of $\mathrm{Ca}^{2+}$ ions is observed to be beneficial for $\mathrm{CO}_{2}$ adsorption; further, the carbonate species is identified.

Key Words: Calcium; Ceria; Scanning tunneling microscopy; X-ray photoelectron spectroscopy; Synchrotron radiation photoemission spectroscopy

\footnotetext{
Received: March 14, 2018; Revised: April 2, 2018; Accepted: April 3, 2018; Published online: April 9, 2018.

*Corresponding authors. Email: husw@ustc.edu.cn (H.S.); jfzhu@ustc.edu.cn (Z.J.); Tel.: +86-551-63602064.

The project was supported by the National Natural Science Foundation of China (U1732272, 21473178, 21403205), National Key Technologies R\&D Program of China (2017YFA0403402), and China Postdoctoral Science Foundation (BH2310000032).

国家自然科学基金(U1732272, 21473178, 21403205), 国家重点研发计划(2017YFA0403402)和中国博士后科学基金(BH2310000032)资助项目
}

(C) Editorial office of Acta Physico-Chimica Sinica 


\title{
$\mathrm{Ca}$ 掺杂的 $\mathrm{CeO}_{2}$ 模型催化剂的形貌和电子结构及其与 $\mathrm{CO}_{2}$ 分子的 相互作用
}

\author{
王岩, 李雄, 胡善玮 ${ }^{*}$, 徐倩, 鞠焕金金, 朱俊发 ${ }^{*}$ \\ 中国科学技术大学化学物理系, 国家同步辐射实验室, 合肥 230029
}

\begin{abstract}
摘要: 利用扫描隧道显微镜、X射线光电子能谱和同步辐射光电子能谱研究了 $\mathrm{CeO}_{2}(111)$, 部分还原的 $\mathrm{CeO}_{2-x}(111)(0<$ $x<0.5)$ 以及 $\mathrm{Ca}$ 掺杂的 $\mathrm{CeO}_{2}$ 模型催化剂的形貌、电子结构以及它们与 $\mathrm{CO}_{2}$ 分子间的相互作用。 $\mathrm{CeO}_{2}$ (111)和部分还原的 $\mathrm{CeO}_{2-x}$ (111)薄膜外延生长于 $\mathrm{Cu}(111)$ 单晶表面。不同 $\mathrm{Ca}$ 掺杂的 $\mathrm{CeO}_{2}$ 薄膜是通过在 $\mathrm{CeO}_{2}$ (111)薄膜表面室温物理沉积金 属 $\mathrm{Ca}$ 及随后真空退火到不同温度而得到的。不同的制备过程导致样品具有不同的表面组成, 化学态和结构。 $\mathrm{CO}_{2}$ 吸附到 $\mathrm{CeO}_{2}$ 和部分还原的 $\mathrm{CeO}_{2}-x$ 表面后导致表面羧酸盐的形成。此外, 相比于 $\mathrm{CeO}_{2}$ 表面, 羧酸盐物种更易在部分还原的 $\mathrm{CeO}_{2-x}$ 表面生成, 而且更加稳定。而在 $\mathrm{Ca}$ 掺杂的氧化铈薄膜表面, $\mathrm{Ca}^{2+}$ 离子的存在有利于 $\mathrm{CO}_{2}$ 的吸附, 且探测到碳酸盐物种的 形成。
\end{abstract}

关键词: 钙; 二氧化铈; 扫描隧道显微镜; X射线光电子能谱; 同步辐射光电子能谱 中图分类号: 0643

\section{Introduction}

Carbon dioxide is of particular interests since it can be utilized in numerous chemical processes, such as dry reforming of methane $\left(\mathrm{CH}_{4}+\mathrm{CO}_{2}\right)$ to produce synthesis gas $\left(\mathrm{CO}+\mathrm{H}_{2}\right)$ and methanol synthesis ${ }^{1,2}$. However, the metal catalysts involving in these reactions undergo serious deactivation due to the coke formation ${ }^{3}$. The use of ceria-based catalysts can alter this situation. $\mathrm{CeO}_{2}$ has superior oxygen storage/release capacity, resulting in the self-cleaning properties of the catalysts that carbon is oxidized by the oxygen from the $\mathrm{CeO}_{2}$ surface ${ }^{4}$. It is therefore understandable that the interaction between the $\mathrm{CeO}_{2}$ surface and $\mathrm{CO}_{2}$ has extensively been investigated in the literatures ${ }^{5-8}$. However, the intermediate species formed from $\mathrm{CO}_{2}$ on ceria is yet unclear. Moreover, it is reported that the reactivity of ceria surface to $\mathrm{CO}_{2}$ can be tuned by introducing $\mathrm{CaO}$, which increases the basic sites for ceria-based catalysts ${ }^{9}$. It has been investigated that $\mathrm{CO}_{2}$ could chemisorb at a regular surface site of $\mathrm{CaO}$, leading to the formation of carbonates ${ }^{10-12}$. Although the presence of $\mathrm{Ca}$ improves the catalytic performance of ceria-based materials in reactions involving $\mathrm{CO}_{2}$, however, the mechanism of the effect of $\mathrm{Ca}^{2+}$ ions on $\mathrm{CO}_{2}$ decomposition is still under debate. For example, Kang et al. ${ }^{13}$ reported that the adding of $\mathrm{Ca}^{2+}$ into ceria-based solid solutions could enhance the oxygen mobility which might account for the improved $\mathrm{CO}_{2}$ splitting reactivity. However, the synergistic effect between $\mathrm{Ca}^{2+}$ and $\mathrm{Ce}^{3+}$ ions was identified on $\mathrm{CaO}-\mathrm{CeO}_{2}$ based oxides to enhance the $\mathrm{CO}_{2}$ activation ${ }^{14}$. Moreover, the fundamental-level investigation of the interaction of $\mathrm{CO}_{2}$ with $\mathrm{CaO}-\mathrm{CeO}_{2}$ surfaces is still lacking, which motivates our current study.

In this work, we investigated the morphologies and electronic structures of stoichiometric $\mathrm{CeO}_{2}(111)$, reduced $\mathrm{CeO}_{2-x}(111)$ $(0<x<0.5)$, and $\mathrm{Ca}$-doped $\mathrm{CeO}_{2}$ model catalysts and their interaction with $\mathrm{CO}_{2}$ by scanning tunneling microscopy (STM),
X-ray photoelectron spectroscopy (XPS), and synchrotron radiation photoemission spectroscopy (SRPES). It is observed that $\mathrm{CO}_{2}$ adsorption on ceria $\left(\mathrm{CeO}_{2}\right.$ and reduced $\left.\mathrm{CeO}_{2-x}\right)$ and $\mathrm{Ca}$ doped $\mathrm{CeO}_{2}$ surfaces exhibits different adsorbed species. Cadoped $\mathrm{CeO}_{2}$ films show different surface structures at different annealing temperatures, which results in different adsorption behaviors of $\mathrm{CO}_{2}$. Moreover, the presence of $\mathrm{Ca}$ in Ca-doped $\mathrm{CeO}_{2}$ films enhances the $\mathrm{CO}_{2}$ adsorption.

\section{Experimental}

The experiments were carried out in two separate ultrahigh vacuum (UHV) systems. STM measurements were performed in a system that comprises three chambers with base pressures all below $1 \times 10^{-8} \mathrm{~Pa}$. The XPS and SRPES measurements were carried out on the Catalysis and Surface Science Endstation at BL11U beamline in the National Synchrotron Radiation Laboratory, Hefei. These two systems have been described in detail previously ${ }^{15,16}$. Briefly, the beamline is connected to an undulator and equipped with two gratings that cover photon energies from 20 to $600 \mathrm{eV}$ with a resolution $(E / \Delta E)$ better than $10^{4}$ at $29 \mathrm{eV}$. All the STM images were recorded at room temperature with the bias of 3-4 V and tunneling current of $0.01-$ $0.05 \mathrm{nA}$ using an etched tungsten tip. The WSXM program ${ }^{17}$ was used to process the STM images. Core level spectra of Ce $3 d, \mathrm{Ca}$ $2 p$, and $\mathrm{O} 1 s$ were acquired with a monochromatic X-ray source using Al $K_{\alpha}$ radiation (1486.6 eV) (SAX 100, VG Scienta, Sweden). Moreover, Ca $2 p$ and $\mathrm{C} 1 s$ spectra were obtained with a photon energy of $420 \mathrm{eV}$, while valence band (VB) spectra were measured at $h v=115 \mathrm{eV}$. All spectra were measure at $0^{\circ}$ with respect to the surface normal.

The $\mathrm{CO}_{2}$ (99.999\%, Wuhan Newradar Special Gas CO., LTD.) adsorption was performed in $10 \mathrm{~L}$ doses $\left(6.5 \times 10^{-6} \mathrm{~Pa}\right.$, $260 \mathrm{~s})$ at $180 \mathrm{~K}$ by backfilling the UHV chamber. 
The $\mathrm{Cu}(111)$ single crystal $(8 \mathrm{~mm}$ diameter and $2 \mathrm{~mm}$ thickness), purchased from Mateck $\mathrm{GmbH}$, Germany, was used as the substrate. $\mathrm{Cu}(111)$ was cleaned by repeated cycles of $\mathrm{Ar}^{+}$ sputtering and annealing until no contaminant could be found by XPS, and a sharp $(1 \times 1)$ LEED pattern was achieved. In this work, we prepared two ceria films, which were $\mathrm{CeO}_{2}(111) / \mathrm{Cu}(111)$ and reduced $\mathrm{CeO}_{2-x}(111)(0<x<0.5)$, and three Ca-doped ceria films, including $\mathrm{Ca} / \mathrm{CeO}_{2}, \mathrm{Ca} / \mathrm{CeO}_{2}-600 \mathrm{~K}$ and $\mathrm{Ca} / \mathrm{CeO}_{2}-800 \mathrm{~K}$. The preparation procedures were as follows.

$\mathrm{CeO}_{2}(111) / \mathrm{Cu}(111)$. Stoichiometric $\mathrm{CeO}_{2}(111)$ films were grown on a clean $\mathrm{Cu}(111)$ substrate at gradually increased substrate temperature by physical vapor deposition of Ce metal (99.9\%, Alfa Aesar, USA) from an electron beam evaporator (EBE-4, Specs, Germany) in $4 \times 10^{-5} \mathrm{~Pa}$ oxygen $(99.999 \%$, Nanjing Shangyuan). After deposition, the films were postannealed at $850 \mathrm{~K}$ for $10 \mathrm{~min}$ in the same oxygen pressure. The monolayer (ML) of the ceria film is defined as O-Ce-O stack normal to the (111) plane with a thickness of $0.31 \mathrm{~nm}{ }^{18}$.

$\mathrm{CeO}_{2-x}(111)(0<x<0.5)$. The partially reduced $\mathrm{CeO}_{2-x}(111)$ films were obtained at a lower oxygen pressure of $9 \times 10^{-6} \mathrm{~Pa}$ during the $\mathrm{Ce}$ deposition followed by annealing in UHV. The ceria films were $2-4 \mathrm{~nm}$ thick.

$\mathrm{Ca} / \mathrm{CeO}_{2}$. The sample of $\mathrm{Ca} / \mathrm{CeO}_{2}$ was prepared by deposition of $1.2 \mathrm{ML} \mathrm{Ca}$ on $\mathrm{CeO}_{2}(111)$ at room temperature. $\mathrm{Ca}(99.5 \%$, Alfa Aesar, America) was physical vapor deposited on the $\mathrm{CeO}_{2}$ surface from a homemade evaporator with the evaporation rate of $0.2 \mathrm{ML} \cdot \mathrm{min}^{-1}$. The $\mathrm{Ca}$ flux was calibrated with a quartz crystal microbalance (QCM) (TMC 13, Prevac, Poland) before deposition. One ML of $\mathrm{Ca}$ is defined as $7.9 \times 10^{14}$ atoms $\cdot \mathrm{cm}^{-2}$, which is the number of oxygen atoms per unit area in the topmost atomic layer of the $\mathrm{CeO}_{2}$ (111) surface ${ }^{19}$

$\mathrm{Ca} / \mathrm{CeO}_{2}-600 \mathrm{~K}$ and $\mathrm{Ca} / \mathrm{CeO}_{2}-800 \mathrm{~K}$. The samples, $\mathrm{Ca} / \mathrm{CeO}_{2}-$ $600 \mathrm{~K}$ and $\mathrm{Ca} / \mathrm{CeO}_{2}-800 \mathrm{~K}$, were obtained by heating $\mathrm{Ca} / \mathrm{CeO}_{2}$ to 600 and $800 \mathrm{~K}$ in $\mathrm{UHV}$, respectively.

\section{Results and discussion \\ 3.1 Characterization of Ceria-Based Model Catalysts}

Firstly, we studied the surface morphologies and electronic structures of ceria-based catalysts. STM images of all samples are displayed in Fig. 1. As shown in Fig. 1a, the stoichiometric $\mathrm{CeO}_{2}$ film exhibits large and flat terraces that completely cover the $\mathrm{Cu}(111)$ surface. The apparent height of $\mathrm{CeO}_{2}$ islands is measured to be $0.30 \mathrm{~nm}$, in agreement with the spacing of O-Ce$\mathrm{O}$ trilayers in the fluorite bulk $\mathrm{CeO}_{2}(111)$ structure $(0.31 \mathrm{~nm}){ }^{18}$. As displayed in the atomic-scale resolution STM image (inset of Fig. 1a), $\mathrm{CeO}_{2}$ displays a well-ordered atomic structure. The measured distance between two adjacent Ce atoms is $0.39 \mathrm{~nm}$, which is consistent with $0.383 \mathrm{~nm}$, the expected surface spacing for $\mathrm{Ce}-\mathrm{Ce}$ in the bulk $\mathrm{CeO}_{2}(111)^{20}$. Reduced $\mathrm{CeO}_{2-x}$ film also has a flat surface and an ordered structure, however, dark spaces are observed on the surface (Fig. 1b). The nature of dark spaces is attributed to the surface defects, which are associated with the missing lattice oxygen atoms or holes ${ }^{18,20-22}$. After the $\mathrm{CeO}_{2}$ surface was deposited 1.2 $\mathrm{ML} \mathrm{Ca}$ at room temperature, the $\mathrm{CeO}_{2}$ surface is fully covered by $\mathrm{Ca}$ islands, as seen in Fig. 1c. The line scan profile shown in the inset of Fig. 1c suggests that the heights of deposited $\mathrm{Ca}$ islands are less than $2.5 \AA(1 \AA=0.1 \mathrm{~nm})$. Fig. $1 \mathrm{~d}$ shows the morphological information of $\mathrm{Ca} / \mathrm{CeO}_{2}-600 \mathrm{~K}$.
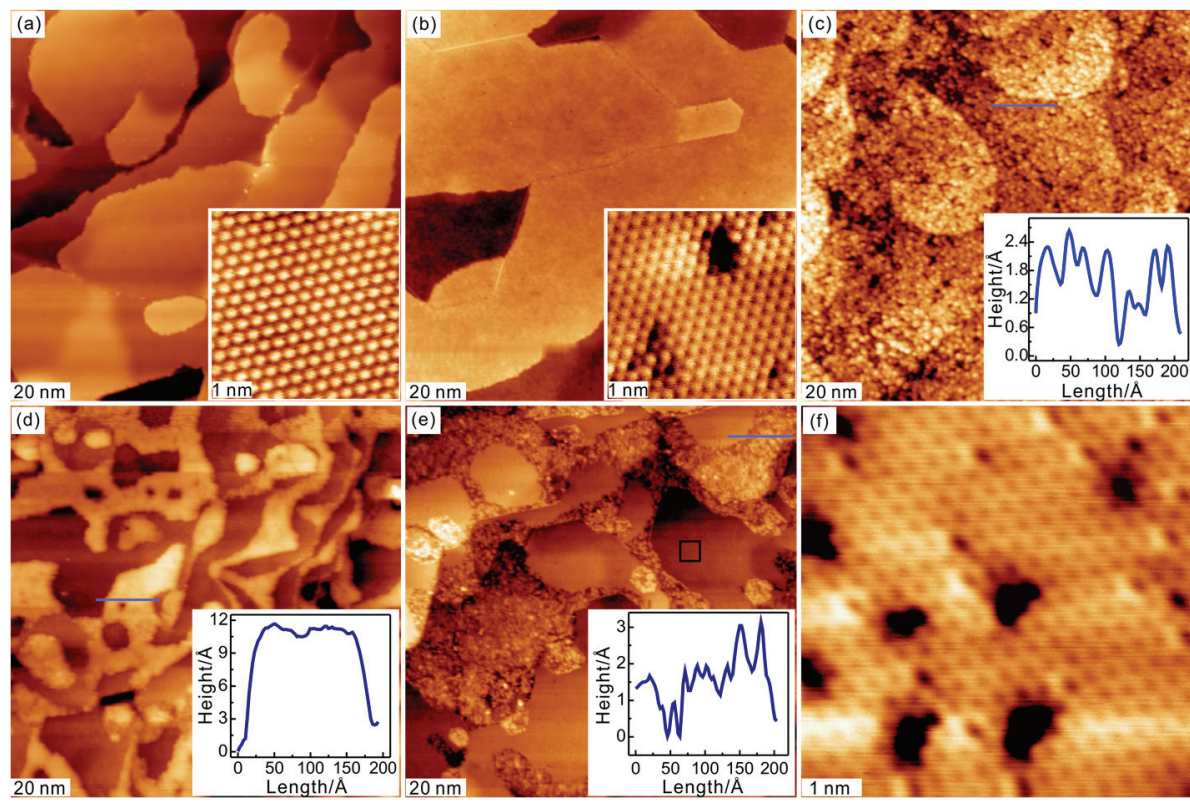

Fig. 1 STM images $(130 \mathrm{~nm} \times 130 \mathrm{~nm})$ of samples: (a) $\mathrm{CeO}_{2}(111)$, (b) $\mathrm{CeO}_{2-x}(111)$, (c) $\mathrm{Ca} / \mathrm{CeO}_{2}$, (d) $\mathrm{Ca} / \mathrm{CeO}_{2}-600 \mathrm{~K}$, and (e) $\mathrm{Ca} / \mathrm{CeO}_{2}-800 \mathrm{~K}$.

The insets of (a) and (b) show the high-resolution STM images $(4.8 \mathrm{~nm} \times 4.8 \mathrm{~nm})$ of $\mathrm{CeO}_{2}(111)$ and $\mathrm{CeO}_{2-x}(111)$, respectively. Panels (c)-(e) include the line scans along the corresponding Ca islands on ceria. (f) Magnified STM image $(6.5 \mathrm{~nm} \times 6.5 \mathrm{~nm})$ of the black framed region in panel (e), showing the detailed structure of the $\mathrm{CeO}_{2}$ substrate for $\mathrm{Ca} / \mathrm{CeO}_{2}-800 \mathrm{~K}$. 
Heating the room temperature deposited $\mathrm{Ca}$ on $\mathrm{CeO}_{2}$ to $600 \mathrm{~K}$ leads to the aggregation of small $\mathrm{Ca}$ islands to large area $\mathrm{Ca}$ islands and part of $\mathrm{CeO}_{2}$ substrate is exposed. As seen in the inset of Fig. 1d, a line scan profile across a large $\mathrm{Ca}$ island indicates that the $\mathrm{Ca}$ island is more than $10.0 \AA$ high. $\mathrm{On} \mathrm{Ca} / \mathrm{CeO}_{2}-800 \mathrm{~K}$ (Fig. 1e), more exposed $\mathrm{CeO}_{2}$ is observed and small $\mathrm{Ca}$ islands are accumulated near terrace step edges. The line scan profile shows that the heights of $\mathrm{Ca}$ islands decrease to less than $2.0 \AA$ (inset of Fig. 1e). Compared with that on $\mathrm{Ca} / \mathrm{CeO}_{2}-600 \mathrm{~K}$, the amount of $\mathrm{Ca}$ nanoparticles on the surface of $\mathrm{Ca} / \mathrm{CeO}_{2}-800 \mathrm{~K}$ decreases. Furthermore, oxygen vacancies are observed on $\mathrm{Ca} / \mathrm{CeO}_{2}-800 \mathrm{~K}$ (Fig. 1f).

To identify the electronic structures of the ceria-based model catalysts, high resolution core-level spectroscopies were investigated. Fig. $2 \mathrm{a}-\mathrm{c}$ display the $\mathrm{Ce} 3 d$ and $\mathrm{Ca} 2 p$ core-level spectra of the studied samples. As shown in Fig. 2a, six peaks are identified in the $\mathrm{Ce} 3 d$ spectrum of the $\mathrm{CeO}_{2}(111)$ film, which correspond to three pairs of spin-orbit split doublets arising from photoemission from $\mathrm{Ce}^{4+}$ ions ${ }^{23,24}$. In the $\mathrm{Ce} 3 d$ spectrum of reduced $\mathrm{CeO}_{2-x}$, four more peaks emerge and are labeled as $\mathrm{u}_{0}$, $\mathrm{u}^{\prime}, \mathrm{v} 0$, and v', which are typical peaks for $\mathrm{Ce}^{3+}$ ions ${ }^{23}$. By fitting the $\mathrm{Ce} 3 d$ spectrum based on the procedure introduced by Skala ${ }^{25,26}$, the percentage of $\mathrm{Ce}^{3+}$ in $\mathrm{CeO}_{2-x}$ can be determined, which is 0.259 (Fig. 2d). Thus this $\mathrm{CeO}_{2-x}$ film is assigned to $\mathrm{CeO}_{1.87}$. The increase of Ce reduction in ceria suggested by XPS agrees well with the increase in the number of oxygen vacancies observed by STM.

$\mathrm{On} \mathrm{Ca} / \mathrm{CeO}_{2}$, the typical peaks for $\mathrm{Ce}^{3+}$ are also visible in the $\mathrm{Ce} 3 d$ spectrum. After fitting this Ce $3 d$ spectrum, the fraction of $\mathrm{Ce}^{3+}$ in $\mathrm{Ca} / \mathrm{CeO}_{2}$ is calculated to be 0.279 (Fig. 2d). This indicates that partial reduction of ceria occurs upon $\mathrm{Ca}$ deposition, which matches with the Ca $2 p$ XPS study shown in Fig. 2b, c. As seen in Fig. 2b, the $\mathrm{Ca} 2 p$ spectrum of $\mathrm{Ca} / \mathrm{CeO}_{2}$ can be easily fitted with one pair of spin-orbit split doublet that is $3.5 \mathrm{eV}$ apart. The $\mathrm{Ca} 2 p_{3 / 2}$ at $346.9 \mathrm{eV}$ is compatible with the reported values for $\mathrm{CaO}^{27-29}$, suggesting that $\mathrm{Ca}$ is oxidized to
$\mathrm{Ca}^{2+}$ on $\mathrm{CeO}_{2}$. This process can be depicted as $\mathrm{Ca}+2 \mathrm{CeO}_{2} \rightarrow$ $\mathrm{Ce}_{2} \mathrm{O}_{3}+\mathrm{CaO}$, which is expected from thermodynamics. Based on $\Delta H_{\mathrm{f}}^{298}$ of oxide formation energy ${ }^{30}$, this process is favored by $253 \mathrm{~kJ} \cdot \mathrm{mol}^{-1}$ at room temperature. Therefore, the $\mathrm{Ca}$ islands on $\mathrm{CeO}_{2}$ observed by STM image (Fig. 1c) are attributed to $\mathrm{CaO}$ nanoislands. However, $\mathrm{CaO}$ film is assembled by the repeating $\mathrm{O}-\mathrm{Ca}-\mathrm{O}$ trilayer ${ }^{31,32}$, and a complete $\mathrm{O}-\mathrm{Ca}-\mathrm{O}$ trilayer is $4.8 \AA$ in height ${ }^{31}$, which is larger than the thickness of $\mathrm{Ca}$ islands (less than $2.5 \AA$ ). Therefore, the $\mathrm{CaO}$ nanoislands are proposed to be $\mathrm{Ca}$ terminated, forming a Ce-O-Ca mixed layer at the $\mathrm{Ca}-\mathrm{CeO}_{2}$ interface. This phenomenon is similar to the case of $\mathrm{Zr}^{16,33}, \mathrm{Al}^{34}$, $\mathrm{Sn}{ }^{25,35}$, and $\mathrm{Mn}^{36}$ on $\mathrm{CeO}_{2}(111)$.

Compared with those from $\mathrm{Ca} / \mathrm{CeO}_{2}$, the characteristic peaks related to $\mathrm{Ce}^{3+}$ in the $\mathrm{Ce} 3 d$ region of $\mathrm{Ca} / \mathrm{CeO}_{2}-600 \mathrm{~K}$ are attenuated, while those due to $\mathrm{Ce}^{4+}$ are intensified (Fig. 2a). Although the $\mathrm{Ca} 2 p$ peak of $\mathrm{Ca} / \mathrm{CeO}_{2}-600 \mathrm{~K}$ shifts to a lower binding energy (Fig. 2b), it still can be assigned to $\mathrm{Ca}^{2+}$ ions, which bond to $\mathrm{O}^{2-}$. This shift may be attributed to the size and structure changes, as seen in STM images (Fig. 1c, d), after annealing. As mentioned above, the thickness of large $\mathrm{Ca}$ islands is two times higher than that of an O-Ca-O trilayer (Fig. 1d), suggesting the formation of $\mathrm{CaO}$ nanofilms with at least two layers thick. The oxygen in these $\mathrm{CaO}$ nanofilms should come from the lattice oxygen of $\mathrm{CeO}_{2}$. However, compared to $\mathrm{Ca} / \mathrm{CeO}_{2}$, the $\mathrm{Ce}^{3+}$ fraction in $\mathrm{Ca} / \mathrm{CeO}_{2}-600 \mathrm{~K}$ even decreases about $\sim 14 \%$ (from 0.28 to 0.244 ) (Fig. 2d). Similar phenomena were observed on Pt-ceria 37 and W-ceria 38 interface upon heating, where the decrease of $\mathrm{Ce}^{3+}$ concentration was attributed to the $\mathrm{Ce}^{3+}$ migration into deeper layers ${ }^{37}$ or the compensation of surface oxygen vacancies by bulk oxygen ${ }^{38}$. The fact that the heights of $\mathrm{CaO}$ nanofilms on $\mathrm{Ca} / \mathrm{CeO}_{2}-600 \mathrm{~K}$ are higher than those of $\mathrm{CaO}$ nanoislands on $\mathrm{Ca} / \mathrm{CeO}_{2}$ suggests that oxygen atoms diffuse from the bulk to the surface.

On the $\mathrm{Ca} / \mathrm{CeO}_{2}-800 \mathrm{~K}$ sample, the $\mathrm{Ce} 3 d$ intensity increases compared with that of $\mathrm{Ca} / \mathrm{CeO}_{2}-600 \mathrm{~K}$. Moreover, $\mathrm{Ce}^{3+}$ concentration in $\mathrm{Ca} / \mathrm{CeO}_{2}-800 \mathrm{~K}$ increases to 0.263 (Fig. 2d),
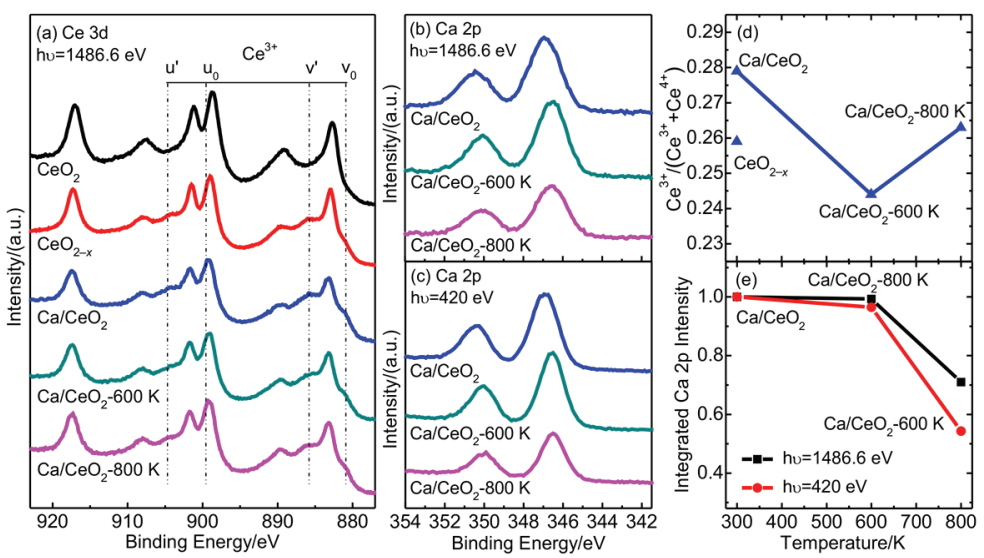

Fig. 2 Core level spectra of (a) $\mathrm{Ce} 3 d$ and (b, c) $\mathrm{Ca} 2 p$ from samples: $\mathrm{CeO}_{2}, \mathrm{CeO}_{2-x}, \mathrm{Ca} / \mathrm{CeO}_{2}, \mathrm{Ca} / \mathrm{CeO}_{2}-600 \mathrm{~K}, \mathrm{and} \mathrm{Ca}_{2} \mathrm{CeO}_{2}-800 \mathrm{~K}$. (a) and (b) are collected with a photon energy of $1486.6 \mathrm{eV}$. (c) is acquired with a photon energy of $420 \mathrm{eV}$. (d) The values of $\mathrm{Ce}^{3+} /\left(\mathrm{Ce}^{3+}+\mathrm{Ce}^{4+}\right)$ in samples: $\mathrm{CeO}_{2-x}(111), \mathrm{Ca} / \mathrm{CeO}_{2}, \mathrm{Ca} / \mathrm{CeO}_{2}-600 \mathrm{~K}$, and $\mathrm{Ca} / \mathrm{CeO}_{2}-800 \mathrm{~K}$. (e) The integrated $\mathrm{Ca} 2 p$ intensities of samples: $\mathrm{Ca} / \mathrm{CeO}_{2}, \mathrm{Ca} / \mathrm{CeO}_{2}-600 \mathrm{~K}$, and $\mathrm{Ca} / \mathrm{CeO}_{2}-800 \mathrm{~K}$ collected at photon energies of 1486.6 and $420 \mathrm{eV}$. 
suggesting that the $\mathrm{CeO}_{2}$ substrate is more reduced. These results match well with the increase in the area of exposed ceria and surface defects indicated by STM images (Fig. 1e, f). On $\mathrm{Ca} / \mathrm{CeO}_{2}-800 \mathrm{~K}$, the $\mathrm{Ca} 2 p$ peak is again assigned to $\mathrm{Ca}^{2+}$. The $\mathrm{Ca} 2 p$ intensity decreases compared with that of $\mathrm{Ca} / \mathrm{CeO}_{2}$ and $\mathrm{Ca} / \mathrm{CeO}_{2}-600 \mathrm{~K}$ (Fig. 2b, c), which is related to the decrease in the $\mathrm{Ca}$ amount on the $\mathrm{CeO}_{2}$ surface observed by STM (Fig. 1e). In addition, the decrease extent is varied between the $\mathrm{Ca} 2 p$ intensity collected at $1486.6 \mathrm{eV}$ and that collected at $420 \mathrm{eV}$.

Fig. 2e displays the $\mathrm{Ca} 2 p$ intensities of Ca-doped samples collected at photon energies of 1486.6 and $420 \mathrm{eV}$. All the Ca $2 p$ intensities were normalized to the corresponding $\mathrm{Ca} 2 p$ intensities of $\mathrm{Ca} / \mathrm{CeO}_{2}$. As can be seen, the $\mathrm{Ca} 2 p$ intensities collected at $1486.6 \mathrm{eV}$ decrease to 0.993 on $\mathrm{Ca} / \mathrm{CeO}_{2}-600 \mathrm{~K}$ and 0.710 on $\mathrm{Ca} / \mathrm{CeO}_{2}-800 \mathrm{~K}$, respectively. While the $\mathrm{Ca} 2 p$ intensities collected at $420 \mathrm{eV}$ decrease to 0.965 on $\mathrm{Ca} / \mathrm{CeO}_{2}-$ $600 \mathrm{~K}$ and 0.543 on $\mathrm{Ca} / \mathrm{CeO}_{2}-800 \mathrm{~K}$, respectively. It is obvious that the $\mathrm{Ca} 2 p$ intensities collected at $420 \mathrm{eV}$ decrease faster compared with those collected at $1486.6 \mathrm{eV}$. Given the fact that $\mathrm{Ca} 2 p$ spectra collected at $420 \mathrm{eV}$ are more surface sensitive than those collected at $1486.6 \mathrm{eV}$, this result is ascribed to the oxygen migration from ceria to the top of $\mathrm{Ca}$ and the diffusion of $\mathrm{Ca}$ into ceria for $\mathrm{Ca} / \mathrm{CeO}_{2}-600 \mathrm{~K}$ and $\mathrm{Ca} / \mathrm{CeO}_{2}-800 \mathrm{~K}$. Particularly, after annealing the $\mathrm{Ca} / \mathrm{CeO}_{2}$ sample to $800 \mathrm{~K}$, more $\mathrm{Ca}$ diffuses into the subsurface of $\mathrm{CeO}_{2}$ to form mixed $\mathrm{CeO}_{2}-\mathrm{CaO}$ oxide, which matches with the STM images (Fig. 1) and the observed intensity increase of Ce $3 d$.

\subsection{Interaction of $\mathrm{CO}_{2}$}

Next we investigate the interaction of $\mathrm{CO}_{2}$ with stoichiometric $\mathrm{CeO}_{2}$ (111), reduced $\mathrm{CeO}_{2-x}(111), \quad \mathrm{Ca} / \mathrm{CeO}_{2}-600 \mathrm{~K}$, and $\mathrm{Ca} / \mathrm{CeO}_{2}-800 \mathrm{~K}$. These samples were exposed to $10 \mathrm{~L} \mathrm{CO}_{2}$ at $180 \mathrm{~K}$ and stepwise heated to higher temperatures in UHV. Fig. 3 illustrates the development of the $\mathrm{C} 1 s$ spectra from $\mathrm{CeO}_{2}$, $\mathrm{CeO}_{2-x}, \mathrm{Ca} / \mathrm{CeO}_{2}-600 \mathrm{~K}$, and $\mathrm{Ca} / \mathrm{CeO}_{2}-800 \mathrm{~K}$ exposed with $10 \mathrm{~L}$ $\mathrm{CO}_{2}$ at $180 \mathrm{~K}$ and subsequent heating to different temperatures. As shown in Fig. 3a and 3b, only one peak at $289.5 \mathrm{eV}$ emerges in the $\mathrm{C} 1 s$ spectra after $\mathrm{CO}_{2}$ exposed on $\mathrm{CeO}_{2}$ and $\mathrm{CeO}_{2-x}$ at 180 $\mathrm{K}$. However, compared with $\mathrm{CeO}_{2}$, the intensity of $\mathrm{C} 1 s$ is stronger on $\mathrm{CeO}_{2-x}$, suggesting much more $\mathrm{CO}_{2}$ can be adsorbed on the reduced ceria, in agreement with our previous study using IRAS ${ }^{5}$. Although the formation of surface carbonate $\left(\mathrm{CO}_{3}^{2-}\right)^{6,39}$ and carboxylate $\left(\mathrm{CO}_{2}^{-}\right)^{40}$ after $\mathrm{CO}_{2}$ adsorption on ceria has been both reported in the literature, using IRAS we have confirmed the formation of carboxylate located over oxygen vacancies ${ }^{5}$. Therefore, we attribute the $\mathrm{C} 1 s$ peak at $289.5 \mathrm{eV}$ to the surface carboxylate. Even on the stoichiometric $\mathrm{CeO}_{2}(111)$, very small amount of oxygen vacancies exists, as demonstrated by angledependent XPS ${ }^{21}$. Therefore, it is understandable that on the reduced ceria surface, the amount of adsorbed $\mathrm{CO}_{2}$ increases. Upon annealing, the $\mathrm{C} 1 s$ signal totally disappears at $260 \mathrm{~K}$ on $\mathrm{CeO}_{2}$ (111), indicating the complete desorption of $\mathrm{CO}_{2}$ from the surface. However, on partially reduced $\mathrm{CeO}_{2-x}(111)$, the $\mathrm{C} 1 s$ peak disappears until the temperature increases to $500 \mathrm{~K}$. This

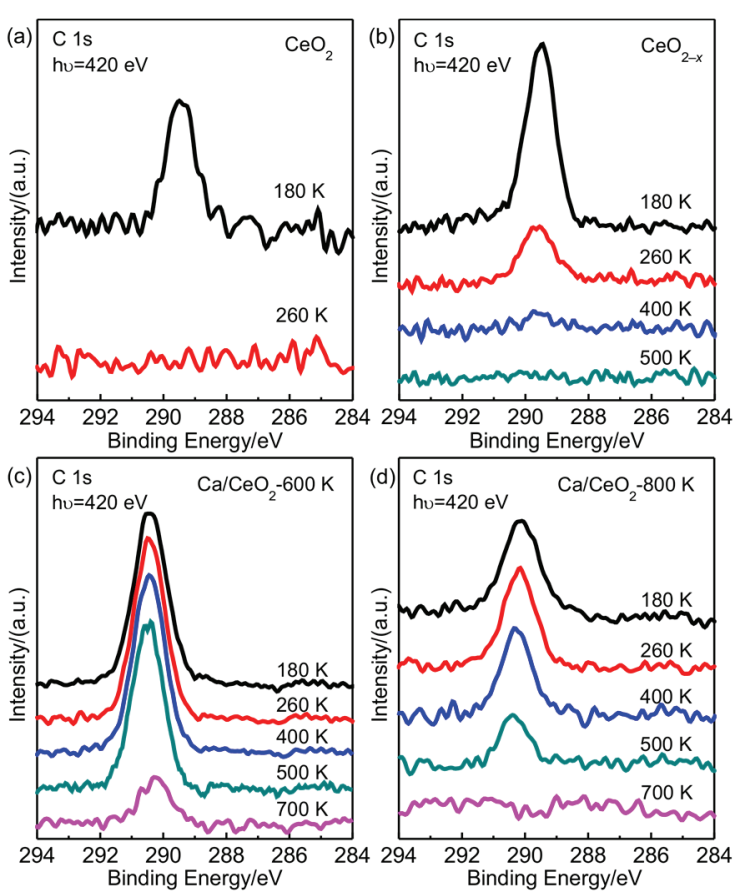

Fig. $3 \mathrm{C} 1 s$ spectra obtained from samples: (a) $\mathrm{CeO}_{2}$, (b) $\mathrm{CeO}_{2-x}$, (c) $\mathrm{Ca} / \mathrm{CeO}_{2}-600 \mathrm{~K}$, and (d) $\mathrm{Ca} / \mathrm{CeO}_{2}-800 \mathrm{~K}$ upon $10 \mathrm{~L} \mathrm{CO}_{2}$ adsorption at

$180 \mathrm{~K}$ and subsequent heating to higher temperatures.

suggests that carboxylates are more stable on reduced $\mathrm{CeO}_{2-x}$ than on the stoichiometric $\mathrm{CeO}_{2}$ surface.

Similar to the observations on ceria surfaces, after $10 \mathrm{~L} \mathrm{CO}_{2}$ adsorption on Ca-doped ceria (i.e., $\mathrm{Ca} / \mathrm{CeO}_{2}-600 \mathrm{~K}$ and $\mathrm{Ca} / \mathrm{CeO}_{2}-800 \mathrm{~K}$ ) at $180 \mathrm{~K}$, also only one peak is observed in the $\mathrm{C} 1 s$ region. As shown in Fig. $3 \mathrm{c}$ and $3 \mathrm{~d}$, the $\mathrm{C} 1 \mathrm{~s}$ peak locates at 290.4 and $290.2 \mathrm{eV}$ on $\mathrm{Ca} / \mathrm{CeO}_{2}-600 \mathrm{~K}$ and $\mathrm{Ca} / \mathrm{CeO}_{2}-800 \mathrm{~K}$, respectively. According to the literature, carbonate species were observed upon $\mathrm{CO}_{2}$ adsorption on $\mathrm{CaO}{ }^{11,12,41}$ and magnesiaceria model catalysts ${ }^{39,42}$. Moreover, carbonate was identified at $290 \mathrm{eV}$ in $\mathrm{C} 1 s$ spectra on Mg-doped ceria ${ }^{42}$. Based on the above discussion, this peak is attributed to the carbonate species. However, it should be mentioned that the nature of the surface species needs more straightforward experimental evidences such as IRAS or theoretical calculations. Nevertheless, since the binding energies of $\mathrm{C} 1 \mathrm{~s}$ spectra from calcium carbonates are reported to be $289.7-291.9 \mathrm{eV}^{43-46}$, we ascribe the peaks at 290.4 and $290.2 \mathrm{eV}$ to $\mathrm{CO}_{3}^{2-}$ formed near $\mathrm{Ca}^{2+}$ ions. After heating $\mathrm{Ca} / \mathrm{CeO}_{2}-600 \mathrm{~K}$ to $500 \mathrm{~K}$, the $\mathrm{C} 1 s$ intensity slightly decreases, with no significant shift in binding energy. Further increasing the temperature to $700 \mathrm{~K}$ leads to a sharp decrease in the $\mathrm{C} 1 \mathrm{~s}$ intensity and a shift of the peak position towards a lower binding energy of $290.2 \mathrm{eV}$. On Ca/CeO $-800 \mathrm{~K}$, between 260 and $500 \mathrm{~K}$, the intensity of the peak associated with $\mathrm{CO}_{3}^{2-}$ species decreases monotonically and the binding energy shifts from $290.2 \mathrm{eV}$ $(180 \mathrm{~K})$ to $290.3 \mathrm{eV}(500 \mathrm{~K})$. Up to $700 \mathrm{~K}$, the peak vanishes in the $\mathrm{C} 1 s$ region.

Fig. $4 \mathrm{a}-\mathrm{c}$ show the $\mathrm{O} 1 s$ spectra of $\mathrm{CeO}_{2-x}, \mathrm{Ca} / \mathrm{CeO}_{2}-600 \mathrm{~K}$, and $\mathrm{Ca} / \mathrm{CeO}_{2}-800 \mathrm{~K}$ with $\mathrm{CO}_{2}$ adsorption at $180 \mathrm{~K}$ and 

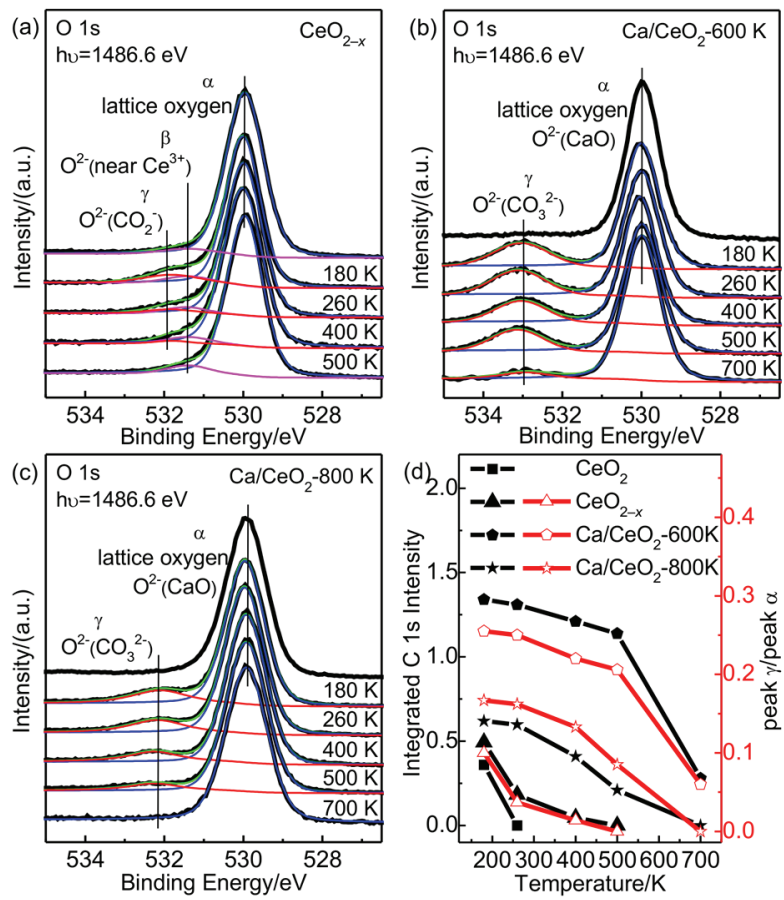

Fig. $4 \mathrm{O} 1 s$ spectra obtained from samples: (a) $\mathrm{CeO}_{2-x}$, (b) $\mathrm{Ca} / \mathrm{CeO}_{2-}$ $600 \mathrm{~K}$, and (c) $\mathrm{Ca} / \mathrm{CeO}_{2}-800 \mathrm{~K}$ upon $10 \mathrm{~L} \mathrm{CO}_{2}$ adsorption at $180 \mathrm{~K}$ and subsequent heating to higher temperatures. The $\mathrm{O} 1 \mathrm{~s}$ spectra of $\mathrm{CeO}_{2-x}$, $\mathrm{Ca} / \mathrm{CeO}_{2}-600 \mathrm{~K}$, and $\mathrm{Ca} / \mathrm{CeO}_{2}-800 \mathrm{~K}$ are plotted as top curves in (a)-(c), respectively. (d) Integrated $\mathrm{C} 1 s$ intensities of $\mathrm{CeO}_{2}, \mathrm{CeO}_{2-x}, \mathrm{Ca} / \mathrm{CeO}_{2}$ $600 \mathrm{~K}$, and $\mathrm{Ca} / \mathrm{CeO}_{2}-800 \mathrm{~K}$ (black) and the intensity ratios of $\mathrm{O} 1 \mathrm{~s}$ peak $\gamma$ to peak $\alpha$ of $\mathrm{CeO}_{2-x}, \mathrm{Ca} / \mathrm{CeO}_{2}-600 \mathrm{~K}$, and $\mathrm{Ca} / \mathrm{CeO}_{2}-800 \mathrm{~K}$ (red) with

$10 \mathrm{~L} \mathrm{CO}_{2}$ adsorption at $180 \mathrm{~K}$ as a function of temperature.

subsequent annealing to different temperatures, respectively. The $\mathrm{O} 1 s$ spectra from $\mathrm{CeO}_{2-x}, \mathrm{Ca} / \mathrm{CeO}_{2}-600 \mathrm{~K}$, and $\mathrm{Ca} / \mathrm{CeO}_{2}-$ $800 \mathrm{~K}$ are shown at the top of each figure. As shown in Fig. 4a, the main peak obtained from $\mathrm{CeO}_{2-x}$ at $530.0 \mathrm{eV}$ (peak $\alpha$ ) appears due to lattice oxygen ${ }^{23}$. A second component (peak $\beta$ ) emerges at $531.4 \mathrm{eV}$, which is attributed to $\mathrm{O}^{2-}$ near $\mathrm{Ce}^{3+}{ }^{23}$. Exposing $\mathrm{CO}_{2}$ to $\mathrm{CeO}_{2-x}$ at $180 \mathrm{~K}$ triggers the attenuation of peak $\alpha$ and the emergence of a new peak at $531.8 \mathrm{eV}$ (peak $\gamma$ ). As the binding energy of peak $\gamma$ is consistent with the reported values of carboxylate ${ }^{5}$, we assign peak $\gamma$ to the $\mathrm{CO}_{2}^{-}$species. Upon heating, the intensity of peak $\gamma$ diminishes monotonically and the peak $\alpha$ increases. After the temperature increases to $500 \mathrm{~K}$, the $\mathrm{O} 1 s$ spectrum is similar to that of pure $\mathrm{CeO}_{2-x}$, suggesting the $\mathrm{CO}_{2}$ desorption from $\mathrm{CeO}_{2-x}$.

As shown in Fig. 4b, one feature at $530.0 \mathrm{eV}$ (peak $\alpha$ ) appears on $\mathrm{Ca} / \mathrm{CeO}_{2}-600 \mathrm{~K}$. This feature is associated with lattice oxygen of ceria. However, according to the literature ${ }^{47}$, the $\mathrm{O} 1 s$ peak of $\mathrm{CaO}$ was reported to be at $530.2 \mathrm{eV}$, which is close to peak of lattice oxygen of ceria. Thus, we cannot exclude the contribution of $\mathrm{O}^{2-}$ in $\mathrm{CaO}$ to peak $\alpha$. Upon $\mathrm{CO}_{2}$ adsorption at $180 \mathrm{~K}$, a peak located at $533.0 \mathrm{eV}$ (peak $\gamma$ ) emerges, which is related to $\mathrm{CO}_{3}^{2-}$ near $\mathrm{Ca}^{2+46}$. Accordingly, the peak $\alpha$ decreases. Upon annealing, the intensity of carbonate $\mathrm{O}$ peak (peak $\gamma$ ) slightly decreases between $180 \mathrm{~K}$ and $500 \mathrm{~K}$ and then sharply decreases up to 700
K. Similarly, after $\mathrm{CO}_{2}$ adsorption on $\mathrm{Ca} / \mathrm{CeO}_{2}-800 \mathrm{~K}$ at $180 \mathrm{~K}$ (Fig. 4c), a new feature associated with $\mathrm{CO}_{3}^{2-}$ near $\mathrm{Ca}^{2+}$ (peak $\gamma$ ) emerges at $532.2 \mathrm{eV}$. The different binding energies of carbonate O peaks for $\mathrm{Ca} / \mathrm{CeO}_{2}-600 \mathrm{~K}$ and $\mathrm{Ca} / \mathrm{CeO}_{2}-800 \mathrm{~K}$ are related to the adsorption of $\mathrm{CO}_{2}$ on $\mathrm{CaO}$ and $\mathrm{CeO}_{2}-\mathrm{CaO}$ mixed oxide. Similar results have been reported for $\mathrm{CO}_{2}$ adsorption on $\mathrm{MgO} / \mathrm{CeO}_{2}$ model catalysts ${ }^{42}$. Increasing annealing temperature leads to the decrease in the intensity of carbonate $\mathrm{O}$ peak. At 500 $\mathrm{K}$, the intensity of the main peak at $530.0 \mathrm{eV}$ (peak $\alpha$ ) recovers to that of clean $\mathrm{Ca} / \mathrm{CeO}_{2}-800 \mathrm{~K}$. The variations of peak $\alpha$ intensities of the studied samples upon $\mathrm{CO}_{2}$ adsorption and subsequent annealing are due to the formation and decomposition of carboxylates on different ceria or carbonates on Ca-doped ceria.

In Fig. $4 d$, the $\mathrm{C} 1 s$ and $\mathrm{O} 1 s$ intensities for $\mathrm{CeO}_{2}, \mathrm{CeO}_{2-x}$, $\mathrm{Ca} / \mathrm{CeO}_{2}-600 \mathrm{~K}$, and $\mathrm{Ca} / \mathrm{CeO}_{2}-800 \mathrm{~K}$ exposed with $10 \mathrm{~L} \mathrm{CO}_{2}$ are plotted as a function of temperature. It is seen that the intensities of $\mathrm{C} 1 s$ after $\mathrm{CO}_{2}$ adsorption formed on the four samples follows the order of $\mathrm{Ca} / \mathrm{CeO}_{2}-600 \mathrm{~K}>\mathrm{Ca} / \mathrm{CeO}_{2}-800 \mathrm{~K}>\mathrm{CeO}_{2-x}>\mathrm{CeO}_{2}$, suggesting that the doping of calcium in $\mathrm{CeO}_{2}$ enhances the $\mathrm{CO}_{2}$ adsorption. Upon heating, all $\mathrm{C} 1 s$ intensities start to decrease, indicating that the surface carboxylates or carbonates start to decompose. Moreover, on ceria surfaces, the $\mathrm{C} 1 s$ intensities decrease much faster upon annealing than those on Ca-doped ceria surfaces, indicating that the surface carboxylates are less stable than carbonates.

The $\mathrm{Ca} 2 p$ spectra of $\mathrm{Ca} / \mathrm{CeO}_{2}-600 \mathrm{~K}$ and $\mathrm{Ca} / \mathrm{CeO}_{2}-800 \mathrm{~K}$ upon $\mathrm{CO}_{2}$ adsorption at $180 \mathrm{~K}$ and subsequent annealing are also investigated. As shown in Fig. 5, after $\mathrm{CO}_{2}$ exposed on $\mathrm{Ca} / \mathrm{CeO}_{2}-$ $600 \mathrm{~K}$ and $\mathrm{Ca} / \mathrm{CeO}_{2}-800 \mathrm{~K}$, the $\mathrm{Ca} 2 p$ spectra are broad and consist of two pairs of spin-orbit split doublets that are $3.5 \mathrm{eV}$ apart. The main $\mathrm{Ca} 2 p_{3 / 2}$ peak on both samples at $346.5 \mathrm{eV}$ is assigned to $\mathrm{Ca}^{2+}$ in $\mathrm{Ca}$-doped ceria. The shoulders at higher binding energies of $347.9 \mathrm{eV}$ on $\mathrm{Ca} / \mathrm{CeO}_{2}-600 \mathrm{~K}$ and $347.3 \mathrm{eV}$ on $\mathrm{Ca} / \mathrm{CeO}_{2}-800 \mathrm{~K}$ are ascribed to $\mathrm{Ca}^{2+}$ in $\mathrm{CaCO}_{3}{ }^{29,48-50}$. This indicates that $\mathrm{Ca}^{2+}$ ions on the $\mathrm{Ca} / \mathrm{CeO}_{2}-600 \mathrm{~K}$ and $\mathrm{Ca} / \mathrm{CeO}_{2}-800$ $\mathrm{K}$ surfaces react with $\mathrm{CO}_{2}$ to form $\mathrm{CaCO}_{3}$. Considering that more $\mathrm{Ca}^{2+}$ diffuses into ceria in the sample of $\mathrm{Ca} / \mathrm{CeO}_{2}-800 \mathrm{~K}$, the
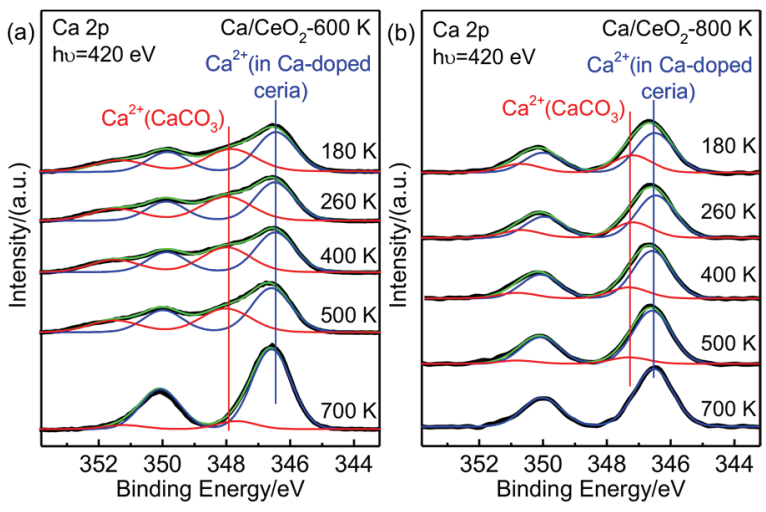

Fig. $5 \mathrm{Ca} 2 p$ spectra of (a) $\mathrm{Ca} / \mathrm{CeO}_{2}-600 \mathrm{~K}$ and (b) $\mathrm{Ca} / \mathrm{CeO}_{2}-800 \mathrm{~K}$ upon $10 \mathrm{~L} \mathrm{CO}_{2}$ adsorption at $180 \mathrm{~K}$ and subsequent heating to higher temperatures. 

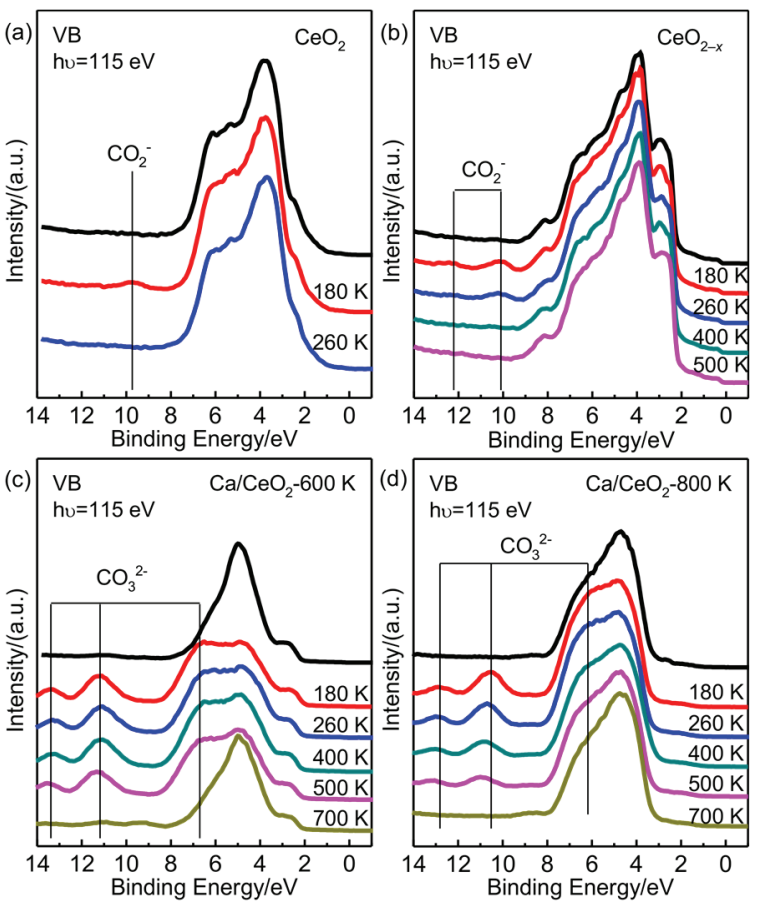

Fig. 6 VB spectra obtained from samples: (a) $\mathrm{CeO}_{2}$, (b) $\mathrm{CeO}_{2-x}$, (c) $\mathrm{Ca} / \mathrm{CeO}_{2}-600 \mathrm{~K}$, and (d) $\mathrm{Ca} / \mathrm{CeO}_{2}-800 \mathrm{~K}$ upon $10 \mathrm{~L} \mathrm{CO}_{2}$ adsorption at $180 \mathrm{~K}$ and subsequent heating to higher temperatures. The VB of $\mathrm{CeO}_{2}, \mathrm{CeO}_{2-x}, \mathrm{Ca} / \mathrm{CeO}_{2}-600 \mathrm{~K}$, and $\mathrm{Ca} / \mathrm{CeO}_{2}-800 \mathrm{~K}$ are plotted as top curves in (a)-(d), respectively.

$\mathrm{CaCO}_{3}$-related $\mathrm{Ca} 2 p$ peak is much weaker compared with that observed on $\mathrm{Ca} / \mathrm{CeO}_{2}-600 \mathrm{~K}$. Upon annealing, the $\mathrm{Ca} 2 p$ peaks related to $\mathrm{CaCO}_{3}$ on both samples undergo slow decrease up to $500 \mathrm{~K}$, followed by fast decrease. After $700 \mathrm{~K}$ annealing, almost no $\mathrm{CaCO}_{3}$-related $\mathrm{Ca} 2 p$ peaks can be observed, suggesting that the $\mathrm{CaCO}_{3}$ species completely decomposes. These results agree well with the $\mathrm{C} 1 s$ and $\mathrm{O} 1 s$ studies (Figs. 3, 4).

Fig. 6a-d display the VB spectra from $\mathrm{CeO}_{2}, \mathrm{CeO}_{2}-x$, $\mathrm{Ca} / \mathrm{CeO}_{2}-600 \mathrm{~K}$, and $\mathrm{Ca} / \mathrm{CeO}_{2}-800 \mathrm{~K}$ exposed with $10 \mathrm{~L} \mathrm{CO}_{2}$ at $180 \mathrm{~K}$ and subsequent annealing to different temperatures. The spectra of the studied samples are plotted as top curves in each figure. Note that the presented spectra were obtained with a photon energy of $115 \mathrm{eV}$, corresponding to the off-resonance condition ${ }^{51}$. The principle features of the VB spectrum measured in off-resonance mode from ceria have been discussed by Mullins et al. ${ }^{23}$. The authors attributed two broad features at 4.5 and $6.5 \mathrm{eV}$ to the $\mathrm{O} 2 p$ orbitals hybridized with $\mathrm{Ce} 4 f$ and $5 d$ orbitals, respectively. Moreover, a feature is observed at $2-3 \mathrm{eV}$ in the VBs of the studied samples. Matolín et al. reported that the features between 0.1 and $4.5 \mathrm{eV}$ in the $\mathrm{VB}$ of continuous $\mathrm{CeO}_{2}(111) / \mathrm{Cu}(111)$ films were assigned to $\mathrm{Ce} 5 d, 6 s, 4 f$ states of $\mathrm{CeO}_{2}{ }^{52,53}$. For $\mathrm{CaO}$, no feature at $2-3 \mathrm{eV}$ is reported to appear in the VB spectrum ${ }^{54}$. Thus, the feature at $2-3 \mathrm{eV}$ is related to the ceria films grown on $\mathrm{Cu}(111)$, which was also observed in some literatures when studying the VBs of ceria films grown on $\mathrm{Cu}(111)^{25,34,35,39,52,53}$. Additional features appear in the VBs of $\mathrm{CeO}_{2}$ and $\mathrm{CeO}_{2-x}$ upon $\mathrm{CO}_{2}$ exposure at $180 \mathrm{~K}$. On $\mathrm{CeO}_{2}$, a feature appears at $9.7 \mathrm{eV}$ (Fig. 6a); on $\mathrm{CeO}_{2-x}$, two features appear at $10.1 \mathrm{eV}$ and $12.2 \mathrm{eV}$, respectively (Fig. 6b). According to the literatures ${ }^{55,56}$, they are related to the carboxylate species. After heating $\mathrm{CeO}_{2}$ to $260 \mathrm{~K}, \mathrm{CO}_{2}$ desorbs from the surface, leading to the disappearance of the feature at $9.7 \mathrm{eV}$, in agreement with the observation of $\mathrm{C} 1 s$ spectra shown in Fig. 3a. While the two features on $\mathrm{CeO}_{2-x}$ gradually decrease upon annealing and completely disappear up to $500 \mathrm{~K}$, indicating that $\mathrm{CO}_{2}^{-}$is much more stable on reduced $\mathrm{CeO}_{2-x}$.

On $\mathrm{Ca} / \mathrm{CeO}_{2}-600 \mathrm{~K}$ (Fig. 6c) and $\mathrm{Ca} / \mathrm{CeO}_{2}-800 \mathrm{~K}$ (Fig. 6d), the broad feature at $5.0 \mathrm{eV}$ in the $\mathrm{VBs}$ is attributed to $\mathrm{O} 2 p$ from oxygen species involved in $\mathrm{Ca}-\mathrm{O}$ bonds ${ }^{46}$. The adsorption of $\mathrm{CO}_{2}$ on both surfaces result in the appearance of three additional features: $6.5,11.2$ and $13.4 \mathrm{eV}$ on $\mathrm{Ca} / \mathrm{CeO}_{2}-600 \mathrm{~K}$ and $6.2,10.6$ and $12.8 \mathrm{eV}$ on $\mathrm{Ca} / \mathrm{CeO}_{2}-800 \mathrm{~K}$; they are ascribed to the $\left(1 \mathrm{a}_{2}\right.$ '; $\left.1 \mathrm{e}^{\prime} ; 4 \mathrm{e}^{\prime}\right)$, (3e'; 1a2'), and $4 \mathrm{a}_{1}$ ' molecular orbitals of $\mathrm{CO}_{3}^{2-}$, respectively ${ }^{54,57}$. Moreover, the evolution of these peaks with annealing temperatures agree well with those observations in the $\mathrm{C} 1 s$, O $1 s$ and Ca $2 p$ studies (Fig. 3-5). These results further support the formation of carboxylates on $\mathrm{CeO}_{2}$ and reduced $\mathrm{CeO}_{2-x}$ and carbonates on Ca-doped ceria upon $\mathrm{CO}_{2}$ adsorption. Moreover, the carboxylates formed on ceria are less stable than carbonates formed on $\mathrm{Ca}$-doped $\mathrm{CeO}_{2}$ samples. In addition, the carbonates on $\mathrm{Ca} / \mathrm{CeO}_{2}-800 \mathrm{~K}$ exhibit a lower thermal stability compared with those on $\mathrm{Ca} / \mathrm{CeO}_{2}-600 \mathrm{~K}$.

\section{Conclusions}

We investigate the morphologies and electronic structures of stoichiometric $\mathrm{CeO}_{2}$ (111), partially reduced $\mathrm{CeO}_{2-x}(111)(0<x<$ $0.5)$, and Ca-doped ceria model catalysts and their interaction with $\mathrm{CO}_{2}$ using STM, XPS, and SRPES. Deposition of 1.2 ML $\mathrm{Ca}$ on $\mathrm{CeO}_{2}$ (111) leads to the immediate reduction of $\mathrm{Ce}^{4+}$ to $\mathrm{Ce}^{3+}$ and oxidation of metallic $\mathrm{Ca}$ to $\mathrm{Ca}^{2+}$. Upon heating to 600 $\mathrm{K}$, large $\mathrm{CaO}$ nanofilms are observed on $\mathrm{CeO}_{2}$. Further increasing the temperature to $800 \mathrm{~K}$, small $\mathrm{CaO}$ islands appear near the step edges and more $\mathrm{Ca}^{2+}$ ions migrate into the subsurface of $\mathrm{CeO}_{2} . \mathrm{CO}_{2}$ adsorption on both stoichiometric $\mathrm{CeO}_{2}$ and reduced $\mathrm{CeO}_{2-x}$ films at $180 \mathrm{~K}$ leads to the formation of surface carboxylate species. Moreover, the reduction of ceria enhances the $\mathrm{CO}_{2}$ adsorption. On Ca-doped ceria films, $\mathrm{CaCO}_{3}$ is identified on the surface. The presence of $\mathrm{Ca}^{2+}$ located on the ceria surface is observed to enhance the $\mathrm{CO}_{2}$ adsorption.

\section{References}

(1) Huang, T. J.; Jhao, S. Y. Appl. Catal. A 2006, 302, 325. doi: 10.1016/j.apcata.2006.02.027

(2) Stacchiola, D. J. Acc. Chem. Res. 2015, 48, 2151. doi: 10.1021/acs.accounts.5b00200

(3) Rostrup-Nielsen, J. R. Catal. Today 1997, 37, 225. doi: 10.1016/S0920-5861(97)00016-3

(4) Wang, X.; Gorte, R. J. Appl. Catal. A 2002, 224, 209. 
doi: 10.1016/S0926-860X(01)00783-9

(5) Kong, D.; Zhu, J.; Ernst, K. H. J. Phys. Chem. C 2016, 120, 5980. doi: 10.1021/acs.jpcc.5b10338

(6) Hahn, K. R.; Iannuzzi, M.; Seitsonen, A. P.; Hutter, J. J. Phys. Chem. C 2013, 117, 1701. doi: 10.1021/jp309565u

(7) Appel, L. G.; Eon, J. G.; Schmal, M. Catal. Lett. 1998, 56, 199. doi: 10.1023/a:1019098121432

(8) Jin, T.; Zhou, Y.; Mains, G. J.; White, J. M. J. Phys. Chem. 1987, 91, 5931. doi: 10.1021/j100307a023

(9) Valenzuela, R. X.; Bueno, G.; Solbes, A.; Sapiña, F.; Martínez, E.; Cortés Corberán, V. Top. Catal. 2001, 15, 181.

doi: 10.1023/a:1016697615043

(10) Pacchioni, G.; Ricart, J. M.; Illas, F. J. Am. Chem. Soc. 1994, 116, 10152. doi: 10.1021/ja00101a038

(11) Kadossov, E.; Burghaus, U. J. Phys. Chem. C 2008, 112, 7390 doi: $10.1021 / j p 800755 q$

(12) Solis, B. H.; Cui, Y.; Weng, X.; Seifert, J.; Schauermann, S.; Sauer, J.; Shaikhutdinov, S.; Freund, H. J. Phys. Chem. Chem. Phys. 2017, 19, 4231. doi: 10.1039/C6CP08504K

(13) Kang, M.; Wu, X.; Zhang, J.; Zhao, N.; Wei, W.; Sun, Y. RSC Adv. 2014, 4, 5583. doi: 10.1039/c3ra45595e

(14) Istadi; Amin, N. A. S. J. Molec. Catal. A: Chem. 2006, 259, 61. doi: 10.1016/j.molcata.2006.06.003

(15) Xu, Q.; Hu, S.; Cheng, D.; Feng, X.; Han, Y.; Zhu, J. J. Chem. Phys. 2012, 136, 154705. doi: 10.1063/1.4704676

(16) Wang, W.; Hu, S.; Han, Y.; Pan, X.; Xu, Q.; Zhu, J. Surf. Sci. 2016, 653, 205. doi: 10.1016/j.susc.2016.07.007

(17) Horcas, I.; Fernández, R.; Gómez-Rodríguez, J. M.; Colchero, J.; Gómez-Herrero, J.; Baro, A. M. Rev. Sci. Instrum. 2007, 78, 013705. doi: $10.1063 / 1.2432410$

(18) Lu, J. L.; Gao, H. J.; Shaikhutdinov, S.; Freund, H. J. Surf. Sci. 2006, 600, 5004. doi: 10.1016/j.susc.2006.08.023

(19) Mullins, D. R.; Radulovic, P. V.; Overbury, S. H. Surf. Sci. 1999, 429, 186. doi: 10.1016/S0039-6028(99)00369-6

(20) Fukui, K. I.; Namai, Y.; Iwasawa, Y. Appl. Surf. Sci. 2002, 188, 252. doi: 10.1016/S0169-4332(01)00917-5

(21) Hu, S.; Wang, Y.; Wang, W.; Han, Y.; Fan, Q.; Feng, X.; Xu, Q.; Zhu, J. J. Phys. Chem. C 2015, 119, 3579. doi: 10.1021/jp511691p

(22) Campbell, C. T.; Peden, C. H. F. Science 2005, 309, 713. doi: $10.1126 /$ science. 1113955

(23) Mullins, D. R.; Overbury, S. H.; Huntley, D. R. Surf. Sci. 1998, 409, 307. doi: 10.1016/S0039-6028(98)00257-X

(24) Pfau, A.; Schierbaum, K. D. Surf. Sci. 1994, 321, 71. doi: 10.1016/0039-6028(94)90027-2

(25) Skála, T.; Šutara, F.; Prince, K. C.; Matolín, V. J. Electron Spectrosc. Relat. Phenom. 2009, 169, 20. doi: 10.1016/j.elspec.2008.10.003
(26) Skála, T.; Šutara, F.; Škoda, M.; Prince, K. C.; Matolín, V. J. Phys.: Condens. Matter 2009, 21, 055005. doi: $10.1088 / 0953-8984 / 21 / 5 / 055005$

(27) Dupin, J. C.; Gonbeau, D.; Vinatier, P.; Levasseur, A. Phys. Chem. Chem. Phys. 2000, 2, 1319. doi: 10.1039/a908800h

(28) Li, S. Q.; Hu, J. S.; Liu, B.; Zhang, G. H.; Cao, W.; Wang, Q.; Zhang, N. Cem. Concr. Res. 1999, 29, 1549. doi: 10.1016/S0008-8846(99)00111-8

(29) Alba-Rubio, A. C.; Santamaría-González, J.; Mérida-Robles, J. M.; Moreno-Tost, R.; Martín-Alonso, D.; Jiménez-López, A.; MairelesTorres, P. Catal. Today 2010, 149, 281. doi: 10.1016/j.cattod.2009.06.024

(30) Barin, I. Thermochemical Data of Pure Substances, 3rd ed.; WileyVCH Verlag GmbH: Weinheim, Germany, 2008; pp. 416-523.

(31) Shao, X.; Myrach, P.; Nilius, N.; Freund, H. J. J. Phys. Chem. C 2011, 115, 8784. doi: 10.1021/jp201852x

(32) Shao, X.; Nilius, N.; Freund, H. J. J. Am. Chem. Soc. 2012, 134, 2532. doi: $10.1021 / \mathrm{ja} 211396 \mathrm{t}$

(33) Hu, S.; Wang, W.; Wang, Y.; Xu, Q.; Zhu, J. J. Phys. Chem. C 2015, 119, 18257. doi: 10.1021/acs.jpcc.5b04325

(34) Skála, T.; Tsud, N.; Prince, K. C.; Matolín, V. Appl. Surf. Sci. 2011, 257, 3682. doi: 10.1016/j.apsusc.2010.11.107

(35) Škoda, M.; Cabala, M.; Cháb, V.; Prince, K. C.; Sedláček, L.; Skála, T.; Šutara, F.; Matolín, V. Appl. Surf. Sci. 2008, 254, 4375. doi: 10.1016/j.apsusc.2008.01.080

(36) Ginting, E.; Hu, S.; Thorne, J. E.; Zhou, Y.; Zhu, J.; Zhou, J. Appl. Surf. Sci. 2013, 283, 1. doi: 10.1016/j.apsusc.2013.05.009

(37) Vayssilov, G. N.; Lykhach, Y.; Migani, A.; Staudt, T.; Petrova, G. P.; Tsud, N.; Skála, T.; Bruix, A.; Illas, F.; Prince, K. C.; et al. Nat. Mater. 2011, 10, 310. doi: 10.1038/nmat2976

(38) Skála, T.; Tsud, N.; Prince, K. C.; Matolín, V. J. Phys.: Condens. Matter 2011, 23, 215001. doi: 10.1088/0953-8984/23/21/215001

(39) Staudt, T.; Lykhach, Y.; Tsud, N.; Skála, T.; Prince, K. C.; Matolín, V.; Libuda, J. J. Phys. Chem. C 2011, 115, 8716. doi: $10.1021 /$ jp200382y

(40) Mudiyanselage, K.; Senanayake, S. D.; Feria, L.; Kundu, S.; Baber, A. E.; Graciani, J.; Vidal, A. B.; Agnoli, S.; Evans, J.; Chang, R. Angew. Chem. Int. Ed. 2013, 52, 5101. doi: 10.1002/anie.201210077

(41) Doyle, C. S.; Kendelewicz, T.; Carrier, X.; Brown, G. E. Surf. Rev. Lett. 1999, 06, 1247. doi: 10.1142/s0218625x99001402

(42) Lykhach, Y.; Staudt, T.; Streber, R.; Lorenz, M. P. A.; Bayer, A.; Steinrück, H. P.; Libuda, J. Eur. Phys. J. B 2010, 75, 89. doi: 10.1140/epjb/e2010-00110-x

(43) Hari, B.; Ding, X.; Guo, Y.; Deng, Y.; Wang, C.; Li, M.; Wang, Z. Mater. Lett. 2006, 60, 1515. doi: 10.1016/j.matlet.2005.11.062

(44) Altrusaitis, J.; Usher, C. R.; Grassian, V. H. Phys. Chem. Chem. 
Phys. 2007, 9, 3011. doi: 10.1039/b617697f

(45) Kovačević, V.; Lučić, S.; Hace, D.; Packham, D.; Šmit, I. Polym Eng. Sci. 1999, 39, 1433. doi: 10.1002/pen.11534

(46) Voigts, F.; Bebensee, F.; Dahle, S.; Volgmann, K.; Maus-Friedrichs, W. Surf. Sci. 2009, 603, 40. doi: 10.1016/j.susc.2008.10.016

(47) Fujimori, Y.; Zhao, X.; Shao, X.; Levchenko, S. V.; Nilius, N.; Sterrer, M.; Freund, H. J. J. Phys. Chem. C 2016, 120, 5565. doi: 10.1021/acs.jpcc.6b00433

(48) Miao, S. Appl. Surf. Sci. 2003, 220, 298. doi: 10.1016/S0169-4332(03)00830-4

(49) Ni, M.; Ratner, B. D. Surf. Interface Anal. 2008, 40, 1356. doi: $10.1002 /$ sia.2904

(50) Shui, M. Appl. Surf. Sci. 2003, 220, 359. doi: 10.1016/S0169-4332(03)00866-3

(51) Staudt, T.; Lykhach, Y.; Tsud, N.; Skála, T.; Prince, K. C.; Matolín, V.; Libuda, J. J. Catal. 2010, 275, 181. doi: 10.1016/j.jcat.2010.07.032

(52) Šutara, F.; Cabala, M.; Sedláček, L.; Skála, T.; Škoda, M.; Matolín, V.; Prince, K. C.; Cháb, V. Thin Solid Films 2008, 516, 6120. doi: 10.1016/j.tsf.2007.11.013

(53) Matolín, V.; Cabala, M.; Cháb, V.; Matolínová, I.; Prince, K. C.; Škoda, M.; Šutara, F.; Skála, T.; Veltruská, K. Surf. Interface Anal. 2008, 40, 225. doi: 10.1002/sia.2625

(54) Ochs, D.; Braun, B.; Maus-Friedrichs, W.; Kempter, V. Surf. Sci. 1998, 417, 406. doi: 10.1016/S0039-6028(98)00721-3

(55) Vohs, J. M.; Barteau, M. A. Surf. Sci. 1988, 201, 481. doi: 10.1016/0039-6028(88)90499-2

(56) von Niessen, W.; Bieri, G.; Åsbrink, L. J. Electron Spectrosc. Relat. Phenom. 1980, 21, 175. doi: 10.1016/0368-2048(80)85046-8

(57) Tegeler, E.; Kosuch, N.; Wiech, G.; Faessler, A. J. Electron Spectrosc. Relat. Phenom. 1980, 18, 23.

doi: 10.1016/0368-2048(80)80002-8 